\title{
Multidisciplinary Synergy of Health Workers as an Effort to Improve Public Health Status \\ Ema Pristi Yunita ${ }^{1,2 *}$ \\ ${ }^{1}$ Departement of Pharmacy, Faculty of Medicine, Universitas Brawijaya, Malang, Indonesia \\ ${ }^{2}$ Research Center of Smart Molecules of Natural Genetic Resource (SMONAGENES), Universitas Brawijaya, Malang, Indonesia
}

Submitted: November 14 ${ }^{\text {th }}$ 2018; Revised: July $3^{\text {rd }}$ 2021; Accepted: August $3^{\text {rd }} 2021$

Keywords:
Health workers
Interprofessional
collaboration
National health
system
Public health

Public health

\begin{abstract}
The low level of public knowledge of the importance of preventing diseases and maintaining health can increase morbidity and mortality. In this community service, counseling and integrated health services were provided by seven health study programs at Universitas Brawijaya (UB). This community service aimed to improve public health status and identify the correlation between education level and public behavior and their health condition. All health workers wrote the health status of the participants on the community health cards. The participants were asked to answer questionnaires as a feedback process and an analysis of the activity. A total of $95.33 \%$ of the participants stated that these activities were useful while $4.67 \%$ stated that the activities were useless. The results of the gamma correlation test showed a significant correlation between education level and public behavior towards complaints about aches and pains, coughs and colds, diarrhea, chest pains, and itching. On complaints about aches and pains and abdominal pain, the higher the education level, the worse the behavior in dealing with the complaints. Collaborative activities among health workers are needed to overcome public health problems. A high education level of the public does not always guarantee the accuracy of certain actions chosen to overcome various early symptoms of diseases. Therefore, the role of health workers is needed in providing health education to the public regardless of their education levels.
\end{abstract}

\section{INTRODUCTION}

The law Number 36 Year 2009 concerning Health article 2 and 3 mandates the government a ssisted by all Indonesian citizens to establish health development based on humanity, balance, benefits, protection, respect for rights and obliga tions, justice, gender, nondiscrimination, and religious norms. The health development focuses on increasing the awareness, willingness, and skills to live a healthy life for everyone in order to a chieve the highest public health status. The National Health System (NHS) has formulated one of the national development goals: the a chievement of hea lthy living skills. The NHS (2009) is a form and an implementation method of health development by the Indonesian government a nd all the nation's elements in increasing the a chievement of health development to a chieve the highest health status, which is an indicator of the success of the Indonesia national development. Public health status reflects the health workers' performance to achieve health indicators, including life expectancy, mortality, and nutritional status. One of the supporting factors in providing quality health services is health resources, including the availability of health workers (Kemenkes RI, 2009).

Health workers a re professionals who have a high level of expertise and a re able to provide services in maintaining and improving health service quality, focusing on the health of patients or the community. Qua lity services can be obtained through collaborative practices among health workers, comprising doctors, dentists, pharmacists, nurses, dietitians, and midwives. The collaboration among these health workers is more

ISSN 2460-9447 (print), ISSN 2541-5883 (online)

${ }^{*}$ Corresponding author : Ema Pristi Yunita

Department of Pharmacy, Faculty of Medicine, Universitas Brawijaya, JIn. Veteran, Ketawanggede, Lowokwaru, Malang 65145, Jawa Timur, Indonesia

Email: emapristi@ub.ac.id 
popular under the term interprofessional colla boration (IPC) (WHO, 2010; Bennett et al., 2011). Therefore, immediately starting, implementing, and developing IPC application in the community is considered essential; thus, the community can directly obtain health services that are integrated and complete. Through this community service, a collaboration of health workers, consisting of general practitioners, pulmonary specialists, neurologists, dentists (oral surgery specia lists), pharmacists, and nutritionists was carried out. In this activity, every health professional was required to actively play a role in improving the public health status a ccording to their respective fields of expertise in an integrated manner among these professionals.

This a ctivity became crucial because it could be a valuable investment that might result in human resources that are socially and economically productive (Law Number 36, 2009). Through the Ministry of Health, the health sector development is also government's major concern as stated in the Susta inable Development Goals (SDGs) in line with the international commitments. This activity focused on achieving the third goal of the SDGs that is combatting severa ldiseases, especially respiratory diseases that are likely experienced by many people (WHO, 2018).

The respira tory disease chosen as the focus of this activity was tuberculosis because its preva lence is still high in Indonesia, and many people still do not understand how to prevent and minimize the spread of this disea se (Media, 2011). The selected location of this activity was Bulan Terang Utama Housing, with a population of approximately more than 1,000 people since Bulan Terang Utama Housing is subsidized housing provided by the government for low-income groups. The people living in this a rea often ignore respira tory diseases by refusing to consult doctors even though when they havecough for months. However, the medical examination, treatment, and counseling services were not only to mitigate respiratory diseases but a lso degenerative and metabolic diseases that often occur in the community, such as hypertension, diabetes mellitus, hyperuricemia, gout, and dyslipidemia. In addition, health services were also provided to examine the nutritional status as well as dental and oral health conditions of the community because periodic examinations on the dental and oral hea th condition had not been considered necessary by the community. For this reason, this activity was hoped to promote public awareness of the importance of having a dental and oral health check up every six months.

Overall, these health services aimed to improve the community's health status. Therefore, it was expected that after this community service activity, the number of morbidity and mortality in the community could be controlled and decreased. In addition, it wa s hoped that the people who participated in this activity can share their knowledge of the importance of preventing disea ses and promote a wareness of lea ding a healthy lifestyle from an early age. The community was also expected to build a closer rela tionship with the health workers and understand the role of each of them. Consequently, it was expected that the people would no longer be hesitant to consult health workers a bout their hea th problems.

Based on the educational and economic background of the target community, health fulfillment had not become a priority. The community considered it a secondary or even tertiary need, so that their health status was ignored, and they had not had a healthy lifestyle. One of the infectious diseases ignored by the target community was respiratory infection. Clearty, this condition was not tolerable because it would endanger themselves and their surrounding environment because respiratory infections are highly transmittable to others. Some residents showed antipathy towards health workers and had never been willing to contact health workers even though when they or their family members had health problems and preferred alternative medicines that they considered sa fer. Ba sed on a nalyzing the situation, the community service consisting of health professionals from Universitas Brawijaya's the Faculty of Medicine and the Faculty of Dentistry initiated a program a imed at improving the public health status of the target community through a $n$ integrated health service.

\section{METHOD}

\subsection{Method, location, time, and duration of activities to solve the problems}

The method used in this health service was counseling for tuberculosis by doctors from the pulmonary specialist education program and therapeutic management by pha macists. In addition, the participants were given the opportunity to ask questions regarding the materials presented. The counseling was then continued by providing integrated health services. These services consisted of the following.

1. Clinical examination by general practitioners, pulmonary specialists, neurologists, and dentists following the history of the disease and complaints or typical symptoms felt by the community members.

2. Vital signs exa mination comprising blood pressure (BP), pulse, and arrhythmias detection. The cla ssification of blood pressure was based on Unger et al. (2020); it is listed a follows:

a. Hypotension if the systolic BP value is lower than $90 \mathrm{mmHg}$. 
b. NormalBP if the systolic BP ranges from 90 to $<130 \mathrm{mmHg}$ and the diastolic BP ranges from 70 to $<85 \mathrm{mmHg}$.

c. High-normal BP if the systolic $\mathrm{BP}$ value ranges from 130-139 $\mathrm{mmHg}$ and diastolic $\mathrm{BP}$ ranges from $85-89 \mathrm{mmHg}$.

d. Gra de 1 hypertension is when the systolic BP is between 140-159 $\mathrm{mmHg}$, and the diastolic BP is between $90-99 \mathrm{mmHg}$.

e. Gra de 2 hypertension if the systolic BP is $\geq 160$ $\mathrm{mmHg}$ and the dia stolic BP is $\geq 100 \mathrm{mmHg}$.

Meanwhile, the classification of pulse frequency was based on Hobohm et al. (2020) and Sidhu \& Marine (2020); the following is the classification.

a. Bradycardia if the pulse rate is below 60 beats/minute.

b. Normocardia if the pulse rate is 60-99 beats/minute.

c. Tachycardia if the pulse rate is $\geq 100$ beats/minute.

Vital signs were checked using a digital sphygmomanometer that could detect irregular heartbeat conditions as it is equipped with pulse arrhythmia detection (PAD).

3. Blood tests, including random blood glucose, uric acid, or total cholesterol by letting the participants choose the type of parameters they wanted to check according to the history of their diseases and complaints or typical symptoms. During this series of tests, the participants were assisted by nurses.

4. Counseling provided by professional and experienced counselors, comprising:

a. Drug therapy booth

This booth prepared and explained how to use the drugs prescribed by doctors. Explanations were given by pharmacists.

b. Balanced-diet booth

This booth provided snacks with a balanced nutritional content and provided information and consultation services regarding a balanced nutritional diet according to the needs and clinical conditions of the patients. Explanations were given by nutritionists aided with lea flets. c. Dentaland oral health booth

This booth provided free toothpaste and toothbrushes for the participants as well as information and consultation services regarding how to maintain oral and dental health. The explanation was given by dentists specializing in oral surgery a ided with lea flets.

d. Wound care booth

This booth provided consultation and treatment services for surgical wounds and diabetic foot wounds (gangrene) by the PedisCare Wound Care Clinic Team. Besides, this booth a lso gave foot exercises for diabetic patients as well as repairblood vessels in the feet and soles so that their va scula rization became better.

This community service program was held at Bulan Terang Utama Housing, $R W$ XVI and $R W$ XVII, Madyopuro Villa ge, Kedungkandang District, Ma lang. This series of activities wa s carried out for 2.5 months, from November 2016 to the second week of January 2017.

\subsection{Data collection and analysis techniques}

Activity evaluation was carried out by considering the following indicators.

1. The enthusiasm of the community in participating in this activity. This a ctivity would be considered successful if the enthusiasm of the community was higher than $80 \%$. The enthusiasm was assessed from the number of people invited (100 people), attended, and queued for the health services provided by the community service team.

2. The people who attended were willing to take the time to fill out the questionnaire instrument containing 21 questions. The questions in the questionnaire were not in the Likert scale or Guttman scale, so validity and reliability tests were not needed. The community service team prepared the questions in the questionnaire by considering the aims to collect data on the respondent's a ttitudes in dealing with complaints related to their health problems and their relationship to the respondents' education levels. This activity would be considered successful if

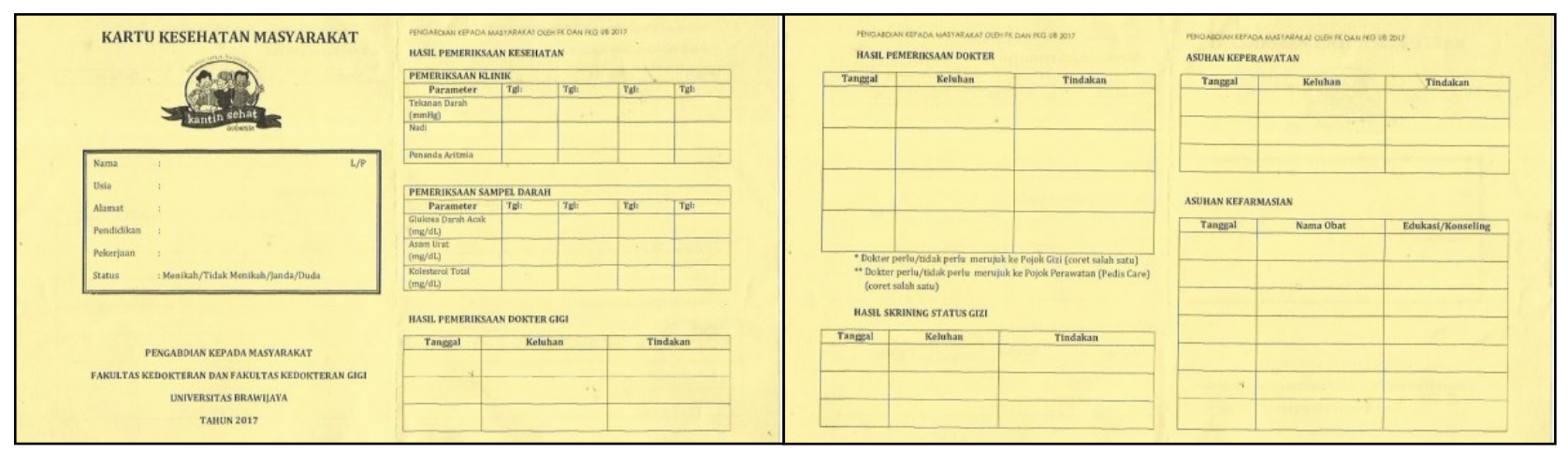

Figure 1. Community health card 
more than $50 \%$ of the people filled out the questionnaire.

3. Obta ining public health status data, consisting of blood pressure and pulse ra te, a well as random blood glucose, uric a cid, and cholesterol levels. These data could help the community service team in providing counseling and interventions for the community.

4. Assessment of the relationships between the community members' educations level and the accuracy of the steps taken in overcoming various early symptoms of diseases. To assess this, questionnaires were used. The education levels were divided into basic (Elementary and Junior High School), middle (Senior High School and Vocational School), and high (Diploma 1, Diploma 3, Undergraduate, and Postgraduate). The people's behavior to deal with symptoms and signs of illness was divided into bad (allowing the illness to selfheal), moderate (drinking herbal medicine, taking medicine from friends, taking medicine from supplies at home, or checking with a traditional healer or sangkal putung), and good (consulting doctors, midwives, nurses, or directly buy medicines at a pharmacy) (Yunita \& Adianingsih, 2017).

\subsection{Hypothesis testing}

The hypothesis test used to analyze the correlation between the participants' education levels and the participants' behavior to overcome the symptoms and signs of their diseases was conducted by using the gamma correlation test. It was because the two connected variables were both ordinal categories. In addition, the gamma correlation test was chosen because the relationship between the compared variables had an equal position (there were no independent and dependent variables)(Dahlan, 2011).

\section{RESULT AND DISCUSSION}

Even though the invitations were sent only to 100 residents, 237 people came and participated in this community service program. This showed that the community had high enthusiasm to partake in the health examination program, so that the number of participants exceeded the specified target. A series of activities held consisted of counseling for tuberculosis and its therapeutic management, medical examination, and measurements of blood pressure, uric acid, cholesterol, and random blood glucose levels. In addition, counseling and education related to drug therapy, dental and oral health, and a balanced nutritional diet were provided. All participants' details, comprising names, a ges, addresses, medical history, and medication were recorded during their registration process. Also, each participant wa s given a community health card (CHC) (see Figure 1), a queue number according to their health service needs, and a questionnaire. The community seemed very enthusiastic to visit the nutrition booth to consult for nutritional status and diet, especially for their children, who were still babies, toddlers, and young children. The community service team from the nutrition department measured the participants' weights and heights to determine their body mass index (BMI) status. By measuring their BMI, the community service team could provide further education about balanced diet patterns to meet healthy nutritional needs for the participants. Everyone who visited the nutrition booth was given healthy and nutritious snacks and information about their nutritional values. Ba sed on research conducted by Rahayu \& Yulidasari (2017), health workers play a role in improving the BMI of adolescents; thus, the nutritional status among a dolescents can be improved.

The dental and oral health booth was also crowded with participants who checked the condition of their teeth. Most participants consulted for cavities. The dental and oral health team explained how to maintain healthy teeth and mouth and how to brush their teeth properly. The education aboutdental and oral health was carried out using leaflets. This education was beneficial for the community members since this could add to their knowledge of taking care of their dental and oral health. Research findings showed that a good understanding of oral health could reduce dental caries (Ramadhan et al., 2016). In addition, respondents with a good level of knowledge had better dental and oral health and healthy lifestyle than those with little knowledge (Setyawati, 2018). As many as 30 people visited this booth, and each of them was lucky to get a free toothbrush and toothpaste as souvenirs. The participants could use these to maintain their dental and oral health. It is in line with research conducted by Ratih \& Yudita (2019), who found that tools a vailability ca $n$ increase respondents' knowledge about how to ma intain good oral and dental health.

The nursing booth sponsored by PedisCare was also visited because the nursing booth was considered new by the community. At this booth, the participants could consult for various wound treatments that can be handled by the nursing team, ranging from burns, surgical wounds, and gangrene wounds on foot to avoid amputation. In addition, at this booth diabetic foot exercises were a lso provided for at least five people that a imed to improve blood circulation in the foot area for both DM and non-DM participants (Wahyuni \& Yuswanto, 2017).

Table 1. Responses of benefits of the community service

\begin{tabular}{llll}
\hline Yes & No & \multicolumn{3}{c}{ Total Respondents } \\
\hline $143(95.33 \%)$ & $7(4.67 \%)$ & $150(100 \%)$ & \\
\hline & WWw.jurna l.ugm .ac.id/jpkm & 156
\end{tabular}


Table 2. Feedback from participants who feel the benefits of the community service

\begin{tabular}{llc}
\hline No. & \multicolumn{1}{c}{ Feedback } & $\begin{array}{l}\text { Number of } \\
\text { Responses }\end{array}$ \\
\hline 1. & $\begin{array}{l}\text { The participants could recognize } \\
\text { their health condition earlier. }\end{array}$ & $53(31.93 \%)$ \\
The participants felt that this & $37(22.29 \%)$ \\
activity enabled them to save & \\
some money as the services were \\
free.
\end{tabular}

At the end of the a ctivity, participants were asked to complete questionnaires to obtain activity feedback and community's behavior in dealing with symptoms of diseases. The participants who filled out the questionnaire were as many as 150 people $(63.29 \%)$ from a total of 237. Most of them (95.33\%) considered that the series of activity ga ve them benefits (Ta ble 1 ). From their feedback regarding the benefits, the top three benefits written by theparticipants were that they could find out their health condition earlier (31.93\%); $22.29 \%$ of the participants felt that this a ctivity enabled them to save some money as these health counseling and examinations were free, and they thought that this activity could increase their knowledge of their diseases $(21.69 \%)$ (see Table 2). Therefore, the feedback showed that the objectives of this program were achieved, and this activity was right on target, namely to help improve the health status of people with low incomes. This community service program was in accordance with research findings showing that health workers play a role in improving the health status of the community through preventive and health promotion measures (Chasanah, 2015; Nurhayati, 2016). However, seven people (4.67\%) stated that this activity was not beneficialbecause they had to queue to get the health services (see Table 1 and Table 3). Moreover, the community service team limited the quota for uric acid, cholesterol, and random blood glucose level examinations because it was impossible to provide as many as 200 quotas for each of the tests due to limited funds. As a result, some participants who did not receive some of the services were disa ppointed.

Table 3. Feedback from participants who did not feel the benefits of the community service

\begin{tabular}{clc}
\hline No. & \multicolumn{1}{c}{ Feedback } & $\begin{array}{c}\text { Number of } \\
\text { Responses }\end{array}$ \\
\hline 1. & $\begin{array}{l}\text { The participants felt that this activity } \\
\text { provided little benefit. } \\
\text { The participants felt disappointed } \\
\text { because they could not get some of the } \\
\text { services. }\end{array}$ & $5(71.43 \%)$ \\
\hline \multicolumn{2}{c}{ Total } & $7(28.57 \%)$ \\
\hline
\end{tabular}

\subsection{Results of participants'vital sign examinations}

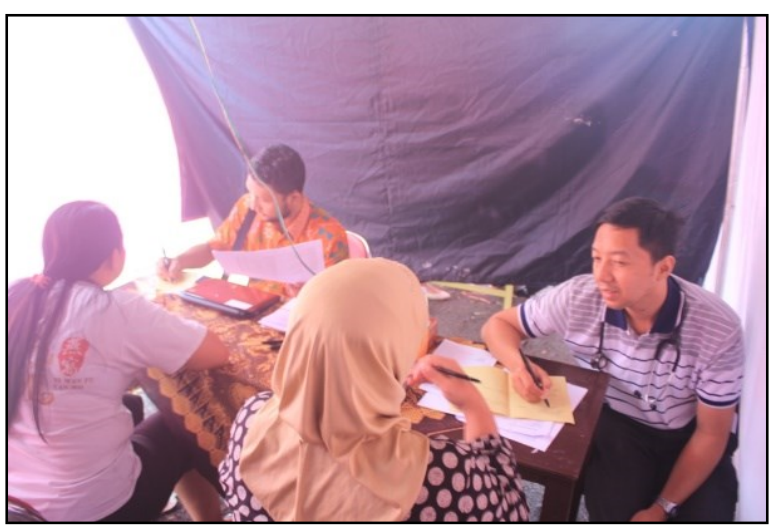

Figure 2. Public health examination by doctors from the community service team

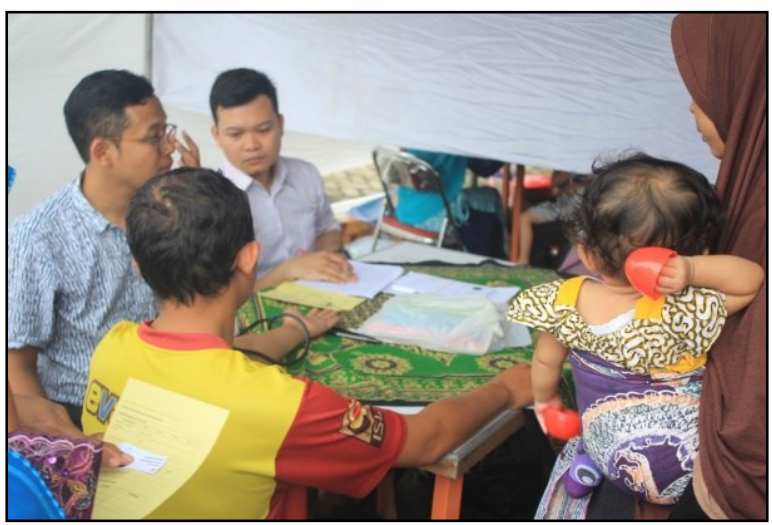

Figure 3. Condition of vital signs examination

When the participants registered, two health workers checked their blood pressures, pulses, and arrhythmias using a digital sphygmomanometer (see Figure 3). The situation at the location, which was crowded with participants, created long queues at the registration desk and at each booth. This condition caused not all participants willing to queue for blood pressure checks, pulse checks, and early detection of a rrhythmias. The number of the participants who had their vita l signs checked was 153 people $(64.56 \%$ ) (see Table 4). The age range of the people participating in this activity was $12-88$ years old. The health services needed by the adolescent a ge group were examinations of dental and oral health, examinations related to complaints of itching and dizziness during 
menstruation, and consultations for nutritional needs. Meanwhile, the needs of the adult and elderly groups were examinations on hypertension conditions, examinations related to complaints of shortness of breath and cough, tension headaches, and digestive disea ses such as chronic ga stritis (see Figure 2), as well as the examinations of uric acid, ra ndom blood glucose, and cholesterol levels.

From the blood pressure examination results, 10 people $(6.54 \%)$ had high-normal BP, 19 people $(12.42 \%)$ had grade 1 hypertension, and 16 people $(10.46 \%)$ had gra de 2 hypertension (see Table 4 ). Based on these data, nearly $50 \%$ of participants were at risk of complications due to their high blood pressures; these complications could include chronic kidney disease, hea rt attack, heart failure, stroke, and vascular dementia (NHLBIa, 2018).

Therefore, in this activity, education and consultation related to blood pressure disorders were provided which comprised non-pharmacological therapy (lifestyle changes) and pharmacological therapy if the dia gnosis of hypertension had been established. Some of the antihypertensive drugs provided included captopril $12.5 \mathrm{mg}$ and $25 \mathrm{mg}$, a mlodipine $5 \mathrm{mg}$ and 10 $\mathrm{mg}$, furosemide $40 \mathrm{mg}$, and ISDN $5 \mathrm{mg}$ for the participants with coronary heart disease(CHD). In this community service program, the drug delivery basedon doctor's prescriptions and the explanation about how to

Tabel 4. Results of participants' examinations on blood pressure, pulse frequency, and arrhythmia

\begin{tabular}{|c|c|c|c|}
\hline Parameter & Total & Percentage (\%) & Mean Value \\
\hline \multicolumn{4}{|l|}{ Gender } \\
\hline Male & 63 & 41.18 & \\
\hline Female & 90 & 58.82 & \\
\hline Total & 153 & 100 & \\
\hline \multicolumn{4}{|l|}{ Age } \\
\hline $10-19$ years & 48 & 31.37 & 15.46 years \\
\hline $20-29$ years & 10 & 6.54 & 24.50 years \\
\hline $30-39$ years & 33 & 21.57 & 35.30 years \\
\hline $40-49$ years & 25 & 16.34 & 44.56 years \\
\hline $50-59$ years & 6 & 3.92 & 56.17 years \\
\hline $60-69$ years & 13 & 8.50 & 64.46 years \\
\hline $70-79$ years & 4 & 2.61 & 71.25 years \\
\hline $80-89$ years & 1 & 0.65 & 88.00 years \\
\hline Data not recorded & 13 & 8.50 & - \\
\hline Total & 153 & 100 & \\
\hline \multicolumn{4}{|l|}{ Systolic blood pressure } \\
\hline $70-89 \mathrm{mmHg}$ & 1 & 0.65 & $88 \mathrm{mmHg}$ \\
\hline $90-119 \mathrm{mmHg}$ & 78 & 50.98 & $109 \mathrm{mmHg}$ \\
\hline $120-139 \mathrm{mmHg}$ & 39 & 25.49 & $126 \mathrm{mmHg}$ \\
\hline $140-159 \mathrm{mmHg}$ & 19 & 12.42 & $146 \mathrm{mmHg}$ \\
\hline $160-179 \mathrm{mmHg}$ & 12 & 7.84 & $170 \mathrm{mmHg}$ \\
\hline$\geq 180 \mathrm{mmHg}$ & 4 & 2.61 & $195 \mathrm{mmHg}$ \\
\hline Total & 153 & 100 & \\
\hline \multicolumn{4}{|l|}{ Diastolic blood pressure } \\
\hline $50-59 \mathrm{mmHg}$ & 1 & 0.65 & $53 \mathrm{mmHg}$ \\
\hline $60-79 \mathrm{mmHg}$ & 87 & 56.86 & $71 \mathrm{mmHg}$ \\
\hline $80-89 \mathrm{mmHg}$ & 25 & 16.34 & $84 \mathrm{mmHg}$ \\
\hline $90-99 \mathrm{mmHg}$ & 27 & 17.65 & $93 \mathrm{mmHg}$ \\
\hline $100-109 \mathrm{mmHg}$ & 8 & 5.23 & $103 \mathrm{mmHg}$ \\
\hline$\geq 110 \mathrm{mmHg}$ & 5 & 3.27 & $120 \mathrm{mmHg}$ \\
\hline Total & 153 & 100 & \\
\hline \multicolumn{4}{|l|}{ Blood pressure (BP) classification* } \\
\hline Hypotension & 1 & 0.65 & $88 / 76 \mathrm{mmHg}$ \\
\hline \multicolumn{4}{|l|}{ (Systolic BP < 90 mmHg) } \\
\hline Normal BP & 108 & 70.59 & $113 / 74 \mathrm{mmHg}$ \\
\hline \multicolumn{4}{|l|}{$(90-<130 / 70-<85 \mathrm{mmHg})$} \\
\hline High-normal BP & 10 & 6.54 & $134 / 89 \mathrm{mmHg}$ \\
\hline$(130-139 / 85-89 \mathrm{mmHg})$ & & & \\
\hline Grade 1 hypertension & 19 & 12.42 & $146 / 91 \mathrm{mmHg}$ \\
\hline$(140-159 / 90-99 \mathrm{mmHg})$ & & & \\
\hline Grade 2 hypertension & 16 & 10.46 & $176 / 103 \mathrm{mmHg}$ \\
\hline \multicolumn{4}{|l|}{$(\geq 160 / \geq 100 \mathrm{mmHg})$} \\
\hline Total & 153 & 100 & \\
\hline \multicolumn{4}{|l|}{ Pulse frequency classification** } \\
\hline Bradycardia $(<60$ times/minutes $)$ & 0 & 0 & - \\
\hline Normocardia (60 - 99 times/minutes) & 128 & 83.66 & 84 times/minutes \\
\hline Tachycardia ( $\geq 100$ times/minutes) & 25 & 16.34 & 111 times/minutes \\
\hline Total & 153 & 100 & \\
\hline \multicolumn{4}{|l|}{ Arrhythmia signs } \\
\hline Experienced arrhythmia & 4 & 2.61 & \\
\hline Did not experience arrhythmia & 149 & 97.39 & \\
\hline Total & 153 & 100 & \\
\hline
\end{tabular}


take the drugs were ca rried out by pharmacists. This is in line with research conducted by Rochmawati et al. (2014) finding that pharmaceutical care in patients with cardiovascular risk factors can improve the patients' cardiovascular condition. In a ddition, pharmaceutical care can provide added value in the patient treatment, so that patients receive drug therapy, special education, and a ttention from pharmacists rega rding the treatment received (Rochmawati et al., 2014). Based on the findings of a research conducted by Puspita et al (2017), health workers contribute to the better compliance of hypertensive patients in undergoing treatment since this disease requires long-term therapy. The digital sphygmomanometer used was a lso able to detect arrhythmias. The examination results revealed that 4 people $(2.61 \%$ ) ha d arrhythmias (impaired heart rhythm). Although this number was low, some of these participants still needed attentions by educating them to have their heart health conditions checked regula rity at health facilities. Untreated arrhythmia conditions cause the heart to be unable to pump enough blood throughout the body. This can harm the heart, brain, and other organs (NHLBIb, 2018).

\subsection{Results of participants' uric acid level examinations}

Medical examinationswere carried out according to the queue numbers distributed at the registration time at each health booth. Participants who were suspected of having elevated blood uric acid levels and had a history of hyperuricemia or gout had their uric acid levels checked. The examination results were recorded by the community service team in the community health cards. The purpose of recording this healthstatus on the cards was that when the participants came at the doctor's booth, the doctors could obtain data regarding their health status, such as blood pressure, pulse frequency, arrhythmia signs, uric acid level, cholesterol, and random blood glucose level. Other health booths, such a s nutrition booth, dental and oral health booth, and nursing booth, were asked to write the participants' health status on the card. The utility of the card was not merely during this series of activity. The community health cards could still be used by the participants in the next health examination in other places (health center, hospital, or private doctor's practice). The examination results of the uric acid levels from 54 participants showed that a many as $81.48 \%$ of the participants' uric acid levels were classified as normal, and as many as $18.52 \%$ were classified as hyperuricemia (see Table 5).

Blood examination service was limited to a maximum of two types for one person (see Figure 4) due to time constraints. In this a ctivity, the community service team could only provide the uric acid level examination for 54 people or $22.78 \%$ of the total participants. Participants who experienced hyperuricemia without symptoms (asymptomatic) did not require drug thera py. The community service team only provided education, so that people could reduce their blood uric acid levels through lifestyle changes, for example by reducing or stop consuming purine-rich foods and beverages (offal, sardines, or liquor) (Perhimpunan Reumatologi Indonesia, 2018). Participants diagnosed with gout or hyperuricemia with special conditions were prescribed a uric acid-lowering drug, na mely allopurinol with a $\mathrm{n}$ initial dose of $100 \mathrm{mg}$ per day. Allopurinol works by inhibiting xanthine oxidase (Khanna et al., 2012). In addition, the patients were also prescribed a pain reliever drug, namely diclofenac sodium $50 \mathrm{mg}$, three times per day, which should only be taken when the patient felt pain (Perhimpunan Reumatologi Indonesia, 2018). The participants took the prescriptions to the phamacy booth to obtain the medicine. The community service team provided education related to drugs when the drugs were given.

\subsection{Results of participants' cholesterol level examination}

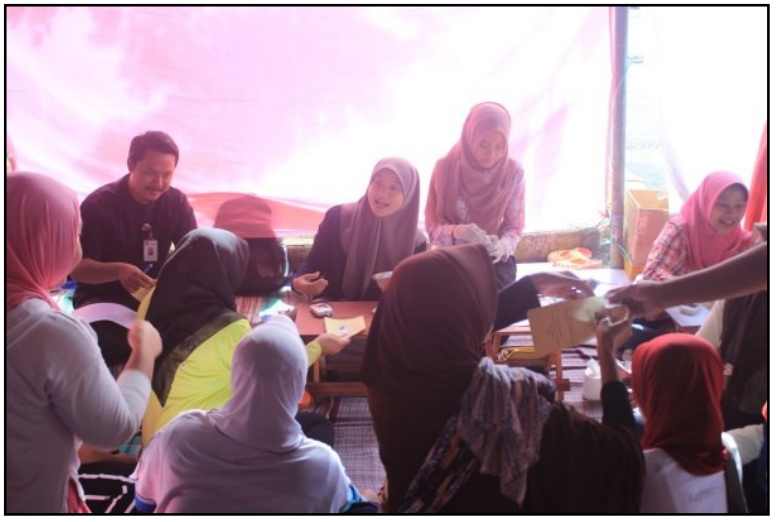

Figure 4. Condition of random blood glucose, uric acid, and cholesterol level examination

The participants who came to the registration desk and complained about aches and pains were often difficult to distinguish whether their cause was due to high uric acid levels (Perhimpunan Reumatologi Indonesia, 2018) or high cholesterol levels. Therefore, in addition to examining the uric acid level, it was necessary to examine the participants' cholesterol levels. Many participants chose cholesterol level exa mination because cholesterol level examinations at public health centers or pharmacies is quite expensive. Unfortunately, the community service team could only provide cholesterol level examinations for 50 people or $21.10 \%$ of the total participants. The reasons why the participants wanted their cholesterol levels checked varied. Some wanted this because they wanted to have routine check due to their history of dyslipidemia, and some other a sked for this test because they complained about aches and pains due to unknown causes or without any history of dyslipidemia. 
The results of the cholesterol level examination were ca tegorized into three groups, namely a cceptable, borderline, and abnormal. In this community service program, 25 people $(50.00 \%)$ had abnormal blood cholesterol levels while 15 people $(30.00 \%)$ and 10 people $(20.00 \%)$ had borderline and acceptable cholesterol levels respectively (see Table 5). The doctors prescribed sim vastatin $10 \mathrm{mg}$ or $20 \mathrm{mg}$ per day depending on each participant's total cholesterol levels and other comorbid diseases. The participants took the prescription to the pharmacy booth to obtain the medicine. The community service team handed over the medicine while providing education that simvastatin should be taken at night because the body produces more total cholesterol and low-density lipoprotein (LDL) than in the morning.

Simva statin has been widely prescribed for the primary or secondary prevention of coronary artery disease. The drug works by inhibiting the enzyme 3 -hydroxy-3methylglutaryl-CoA (HMG-CoA) reductase, an enzyme that controls cholesterol synthesis in the liver (Zodda et al., 2018).

Another education delivered by the community service team was that the community needed to have routine checks at any health center a fter this program to monitor and control their dyslipidemia status. Sometimes, dyslipidemia occurs due to high triglyceride levels, not total or high LDL cholesterol. This condition requires trea tments using other drugs, na mely a torvastatin for moderate hypertrigly ceridemia or fibrates for severe and very severe hypertriglyceridemia, which can increase the risk of pancreatitis (Berglund et al., 2012). However, these drugs were not provided during this activity. In addition, the triglyceride level examination must be carried out in a laboratory because it cannot be checked using the equipment used during this community service program.

\subsection{Results of participants' random blood glucose (RBG) test}

The participants in families with a history of diabetes mellitus (DM) or showing clinical signs that could lead to DM were given queue numbers for the RBG test. The clinical signs included polyuria, polydipsia, polyphagia, or experiencing unexplained weight loss despite eating a lot (The National Diabetes Services Scheme, 2015; ADA, 2018). The number of participants who underwent RBG tests was 55 people, $23.21 \%$ of the total participants. The RBG level tests showed that most participants experienced hyperglycemia $(12.73 \%)$ while the rest experienced hypoglycemia $(5.45 \%)$ and had normal blood glucose levels $(81.82 \%)$ (see Table 5$)$.

The oral antidiabetic drugs provided during this activity were metformin $500 \mathrm{mg}$ and glibenclamide 5 $\mathrm{mg}$. Metformin is a biguanide (Song, 2016) that works by increasing insulin receptor sensitivity (Rena et al., 2017) while glibenclamide is an insulin secretagogue that works by increasing insulin production from $\beta$ pancreatic cells (Inzucchi et a 1., 2012; Pa ndarekandy et a 1., 2017). During this activity, insulin pens were not provided. If the participants required insulin injection, prescriptions were given to the participants, and they could purchase the medication at a pharmacy. In this a ctivity, two people with high RBG levels that could be included in the hyperglycemic crisis category were found, 301 and $419 \mathrm{mg} / \mathrm{dL}$. However, these people had not shown significant clinical manifestations and were not aware of their condition because they never had their health conditions checked previously. For this reason, the community service team educated the participants to undergo further examinations rega rding

Table 5. Results of uric acid, cholesterol, and random blood glucose level examinations

\begin{tabular}{|c|c|c|c|}
\hline Parameter & Total & Percentage $(\%)$ & Mean Value \\
\hline \multicolumn{4}{|l|}{ Uric acid level* } \\
\hline \multicolumn{4}{|l|}{ Normal for men } \\
\hline$(3.0-7.0 \mathrm{mg} / \mathrm{dL})$ & 12 & 22.22 & $5.41 \mathrm{mg} / \mathrm{dL}$ \\
\hline \multicolumn{4}{|l|}{ Normal for women } \\
\hline$(2.2-5.7 \mathrm{mg} / \mathrm{dL})$ & 19 & 35.19 & $4.56 \mathrm{mg} / \mathrm{dL}$ \\
\hline \multicolumn{4}{|l|}{ Hyperuricemia for men } \\
\hline$(>7.0 \mathrm{mg} / \mathrm{dL})$ & 8 & 14.81 & $7.48 \mathrm{mg} / \mathrm{dL}$ \\
\hline \multicolumn{4}{|l|}{ Hyperuricemia for women } \\
\hline Total & 54 & 100 & \\
\hline \multicolumn{4}{|l|}{ Cholesterol level** } \\
\hline Acceptable $(<170 \mathrm{mg} / \mathrm{dL})$ & 10 & 20.00 & $146.20 \mathrm{mg} / \mathrm{dL}$ \\
\hline Borderline $(170$ - $199 \mathrm{mg} / \mathrm{dL})$ & 15 & 30.00 & $187.80 \mathrm{mg} / \mathrm{dL}$ \\
\hline Abnormal $(\geq 200 \mathrm{mg} / \mathrm{dL})$ & 25 & 50.00 & $237.84 \mathrm{mg} / \mathrm{dL}$ \\
\hline Total & 50 & 100 & \\
\hline \multicolumn{4}{|l|}{ Random blood glucose level*** } \\
\hline Hypoglycemia $(\leq 70 \mathrm{mg} / \mathrm{dL})$ & 3 & 5.45 & $60.00 \mathrm{mg} / \mathrm{dL}$ \\
\hline Normoglycemia $(71-199 \mathrm{mg} / \mathrm{dL})$ & 45 & 81.82 & $100.78 \mathrm{mg} / \mathrm{dL}$ \\
\hline Hyperglycemia ( $\geq 200 \mathrm{mg} / \mathrm{dL})$ & 7 & 12.73 & $276.43 \mathrm{mg} / \mathrm{dL}$ \\
\hline Total & 55 & 100 & \\
\hline \multicolumn{4}{|l|}{$\begin{aligned} \text { Source: } & * \text { Yunita et al. (2018) } \\
& * * \text { Grundy etal. (2019) }\end{aligned}$} \\
\hline
\end{tabular}


their DM conditions at the nearest health center or hospital.

\subsection{Gamma correlation hypothesis test results} Table 6. Gamma correlation test results for various complaints

\begin{tabular}{cccc}
\hline No. & Complaints & $\boldsymbol{r}$ & $\boldsymbol{p}$ \\
\hline 1. & Aches and pains & -0.287 & $0.021^{*}$ \\
2. & Cough and cold & 0.400 & $0.000^{*}$ \\
3. & Shortness of & 0.283 & 0.093 \\
& breath & & \\
4. & Diarrhea & 0.367 & $0.027^{*}$ \\
5. & Vomiting & 0.054 & 0.728 \\
6. & Fever & 0.062 & 0,706 \\
7. & Fracture & 0.254 & 0.239 \\
8. & Chest pain & 0.388 & $0.046^{*}$ \\
9. & Itching & 0.435 & $0.004^{*}$ \\
10. & Headache & 0.043 & 0.763 \\
11. & Stomachache & -0.107 & 0.522 \\
12. & Toothache & 0.147 & 0.476 \\
13. & Pregnancy & 1.000 & 0.301 \\
\hline Note: $*$ There is a significant correlation between the participants'
\end{tabular}

education levels and their behavior towards complaints.

The questionnaires given to the community regarding the education level and the steps taken to addresscomplaints that may be an early sign of disease were analyzed. The categorized data were then tested using the gamma correlation test. The test results showed that there were significant correlations (see Table 6) between the participants' education levels and their behavior to deal with complaints of aches and pains $(\mathrm{p}=0.021)$, cough and cold $(\mathrm{p}=0.000)$, diamea $(\mathrm{p}=0.027)$, chest pain $(\mathrm{p}=0.046)$, and itching $(\mathrm{p}=$ $0.004)$. The results of this community service activity are in line with those of the research conducted by Pra dono \& Sulistyowati (2014) showing that education level $(47.1 \%)$ significantly contributes $(55 \%)$ to a person's health status. The correlation strength of complaints of aches and pains, dia rrhea, and chest pain was weak ( $\mathrm{r}$ values of $-0.287,0.367$, and 0.388 respectively). In contrast, the correlation strength of complaints of cough and cold and itching was moderate $(r=0.400$ and $r=0.435$, respectively). Other complaints analyzed did not show significant correlations with community behavior $(\mathrm{p}>0.05)$. The test concluded that a higher education level of a person does not guarantee the a ccuracy of the steps he/shetook in overcoming his/her various early symptoms of his/her disease, especially in overcoming aches and pains and stomach ache. In both complaints, the direction of the correlation was negative, which means that the higher the participants' education level, the worse their behavior in dealing with their complaints. Therefore, the health workers still needed to educate this community about health without considering their education level. It is a lso in line with resea rch findings showing that health workers are important in supporting public health status improvement through education using various media, such as posters, banners, and presentations (Keswa ra et al., 2019).

\section{CONCLUSION}

This community service activity was considered successful because the people who attended this progra m had surpassed the target, were willing to listen a ttentively to the counseling from the beginning to end, and were willing to queue for the health services provided. In addition, the number of people willing to take the time to complete the questionnaire with 21 items of questions exceeded the target $(>50 \%)$. The community service team consisting of health workers from seven fields of expertise wa s also present to serve the participants until the end of the program. Most of the target community members wanted this activity to be held regularly because they could feel its benefits. This activity raised people's awareness of the importance of undergoing routine health examinations, especially for people with a history of certain diseases or people with a history of metabolic diseases in their fa mily. Providing education about health to the public a lso needs to be done regularly without considering their education levels.

\section{ACKNOWLEDGMENT}

The author would like to thank all those who helped implement this community service program, so that it could run well. These parties were the administrators of RW XVI and RW XVII of Bulan Terang Utama Housing in Ma lang, lecturers, students, and the alumni of the Pharmacy Study Program, Faculty of Medicine, and Universitas Brawijaya (FMUB), pharmacists from pharmacies and hospitals, lecturers, students, and a lumni of the Medical Education Study Program FMUB, doctors, and students of pulmonary specialist FMUB, doctors and students of neurologists FMUB, general practitioner of Saiful Anwar General Hospital, lecturers and students of Faculty of Dentistry, Universitas Brawijaya, lecturers and students at FMUB Nutrition Science Study Program, and lecturers of FMUB Nursing Science Study Program, and nurses from PedisCare. The author also expresses her gra titude for the financial support for this community service program from the DPP/SPP Grant Program for the Fiscal Year 2016 Research and Community Service Agency of FMUB under the Contract Letter Number 21/SK/UN10.7/BPPM/2016.

\section{REFERENCES}

American Diabetes Association (ADAb). (2018). Diabetes symptoms. Website: http://www.diabetes.org/diabetes-

basics/symptoms/ (accessed on November 1, 2018).

Bennet, P.N., Gum, L., Lindeman, I., Lawn, S., McAllister, S., Richards, J., et al. (2011). Faculty perceptions of interprofessional education. Nurse Education Today, 31, 571-576. https://doi.org/10.1016/j.nedt.2010.09.008 
Berglund, L., Brunzell, J.D., Goldberg, A.C., Goldberg, I.J., Sacks, F., Murad, M.H., et al. (2012). Evaluation and treatment of hypertriglyceridemia: An Endocrine Society Clinical Practice Guideline. The Journal of Clinical Endocrinology \& Metabolism, 97(9), 2969-2989. https://doi.org/10.1210/jc.20113213

Chasanah, S.U. (2015). Peran petugas kesehatan masyarakat dalam upaya penurunan angka kematian ibu pasca MDGs 2015. Jurnal Kesehatan Masyarakat Andalas, 9(2), 73-79. https://doi.org/10.24893/jkma.v9i2.190

Dahlan, M.S. (2011). Statistik untuk kedokteran dan kesehatan, 5th Edition, Jakarta: Salemba Medika, pp. 180-183.

Grundy, S.M., Stone, N.J., Bailey, A.L., Beam, C., Birtcher, K.K., Blumenthal, R.S., et al. (2019). Guideline on the management of blood cholesterol. Circulation, 139, e1046-e1081. https://doi.org/10.1161/CIR.0000000000000624

Hobohm, L., Becattini, C., Ebner, M., Lerchbaumer, M.H., Casazza, F., Hasenfuß, et al. (2020). Definition of tachycardia for risk stratification of pulmonary embolism. European Journal of Internal Medicine, 82, 76-82. https://doi.org/10.1016/j.ejim.2020.08.009

Perhimpunan Reumatologi Indonesia.(2018). Pedoman diagnosis dan pengelolaan gout, Jakarta: Perhimpunan Reumatologi Indonesia, pp. 1-24.

Inzucchi, S., Rosenstock, J., Umpierrez, G. (2012). Type 2 diabetes and insulin secretagogues. Hormone Health Network. Website: https://www.hormone.org/diseases-andconditions/diabetes/medicines-andtreatment/insulin-secretagogues (accessed on November 1, 2018).

Keputusan Menteri Kesehatan Republik Indonesia (Kemenkes RI). $2009 . \quad$ Nomor. 374/MENKES/SK/V/2009 tentang Sistem Kesehatan Na sional.pp. 1-32.

Keswara, U.R., Wahyudi, D.A., Sari, W.E.P. (2019). Pengetahuan, sikap dan peran tenaga kesehatan terha dap penerapan Pola Hidup Bersih dan Sehat (PHBS) rumah tangga. Holistik Jurnal Kesehatan, 13(1), 37-47. https://doi.org/10.33024/hjk.v13i1.1128

Khanna, D., Fitzgerald, J.D., Khanna, P.P., Bae, S., Singh, M.K., Neogi, T., et al. (2012). American College of Rheumatology Guidelines for management of gout. Arthritis Care \& Research, 64(10), 1431-1446. https://doi.org/10.1002/acr.21772

Media, Y. (2011). Pengetahuan, sikap dan perilaku masyarakat tentang enyakit tuberkulosis (TB) paru di Kecamatan Sungai Tarab, Kabupaten Tanah Datar, Propinsi Sumatera Barat. Media Litbang Kesehatan, 21(2), 82-88. https://doi.org/10.22435/mpk.v21i2 Jun.108

Morales, J. \& Schneider, D. (2014). Hypoglycemia. The American Journal of Medicine, 127(10A), S17-
S24.

https://doi.org/http://dx.doi.org/10.1016/j.amjm ed.2014.07.004

National Heart, Lung, and Blood Institute (NHLBIa). (2018). High blood pressure. Website: https://www.nhlbi.nih.gov/health-topics/highblood-pressure (a ccessed on October 31, 2018).

National Heart, Lung, and Blood Institute (NHLBIb). (2018). Arrhythmia. Website: https://www.nhlbi.nih.gov/healthtopics/arrhythmia (accessed on October 31, 2018).

Nurhayati, M. (2016). Peran tenaga medis dalam pelayanan kesehatan masyarakat di puskesmas pembantu Linggang Amer Kecamatan Linggang Bigung Kabupaten Kutai Barat. ejoumal Administrasi Negara, 4(1), 2127-2140.

Pandarekandy, S.T., Sreejesh, P.G., Thampi, B.S.H., Sreekumaran, E. (2017). Hypoglycaemic effect of glibencla mide: a critical study on the basis of creatinine and lipid peroxidation status of streptozotocin-induced diabetic rat. Indian Journal of Pha maceutical Sciences, 79(5), 768777. https://doi.org/10.4172/pharmaceuticalsciences. 1000290

Pradono, J. \& Sulistyowati, N. (2014). Hubungan antara tingkat pendidikan, pengetahuan tentang kesehatan lingkungan, perilaku hidup sehat dengan status kesehatan studi korelasi pada penduduk umur 10-24 tahun di Jakarta Pusat. Buletin Penelitian Sistem Kesehatan, 17(1), 8995.

Puspita, E., Okta viarini, E., Santik, Y.D.P. (2017). Peran keluarga dan petugas kesehatan dalam kepa tuhan pengobatan penderita hipertensi di Puskesmas Gungpati Kota Semarang. Jurnal Keseha tan Masyarakat Indonesia, 12(2), 25-32.

Rahayu, A. \& Yulidasari, F. (2017). Peranan tenaga kesehatan dalam memperbaiki Indeks Massa Tubuh menurut umur (IMT/U) remaja melalui program School Health Report, Darnoto, S. editor, Prosiding semnas dan call for papers prodi kesehatan masyarakat: peran organisasi profesi dalam ikut serta meningkatkan kompetensi tenaga kesehatan masyarakat, Surakarta: Muhammadiyah University Press, pp. 1-5.

Ramadhan, A., Cholil, C., Sukmana, B.I. (2016). Hubungan tingkat pengetahuan kesehatan gigi da n mulutterhadap a ngka karies gigi di SMPN 1 Marahaban. Dentino Jurnal Kedokteran Gigi, I(2), 173-176.

Ratih, I.A.D.K. \& Yudita, W.H. (2019). Hubungan tingkat pengetahuan tentang cara memelihara kesehatan gigi dan mulut dengan ketersediaan alat menyikat gigi pada narapidana kelas IIB Rutan Gianyar tahun 2018. Jurnal Kesehatan Gigi, 6(2), 23-26.

Rena, G., Hardie, D.G., Pearson, E.R. (2017). The mechanisms of action of metformin. 
Diabetologia, $\quad 60, \quad 1577-1585$. https://doi.org/10.1007/s001 25-017-4342-z

Rochmawati, I.D., de Queljoe, D., Dewi, N., Fatmah, U. (2014). Pengaruh pharmaceutical care pada faktor risiko kardiovaskular pasien di apotek. Jurnal Farmasi Klinik Indonesia, 3(1), 24-29. https://doi.org/10.15416/ijcp.2014.3.1.24

Setyawati, N. (2018). Hubungan antara tingkat pengetahun dengan perila ku kesehatan gigi dan mulut ibu hamil di Puskesmas Dlingo II tahun 2017, Thesis, Yogyakarta: Politeknik Kesehatan Kemenkes Yogyakarta, pp. 1-94.

Sidhu, S. \& Marine, J.E. (2020). Evaluating and managing bra dycardia. Trends in cardiovascular medicine, $\quad 30, \quad 265-272$. https://doi.org/10.1016/j.tcm.2019.07.001

Song, R. (2016). Mechanism of metformin: a tale of two sites. Diabetes Care, 39, 187-189. https://doi.org/10.2337/dci15-0013

The National Diabetes Services Scheme (NDSS). (2015). Type 2 diabetes. Website: https://www.diabetesaustralia.com.au/type-2diabetes (accessed on November 1,2018).

Undang-Undang Nomor 36 Tahun 2009 tentang Kesehatan,p. 5.

Unger, T., Borghi, C., Charchar, F., Khan, N.A., Poulter, N.R., Prabhakaran, D., et al. (2020). International society of hypertension global. Hypertension, 75, 1334-1357. https://doi.org/10.1161/HYPERTENSIONAHA. 120.15026

Wahyuni, T.D. \& Yuswanto, T.J.A. (2017). Combination of DM gymnastics and foot gymnastics toward peripheral vascular neuro on type II diabetes mellitus clients. International Journal of Science and Research, 6(3), 4149. https://doi.org/ 10.21275/ART20171301

World Health Organization(WHO). (2010). Framework for action on interprofessional education \& collaborative practice. Switzerland: The Health Professions Network Nursing and Midwifery Office.pp. 1-62.

World Health Organization(WHO). (2018). Sustainable Development Goals (SDGs). Website: https://sustainabledevelopment.un.org/?menu=1 300 (accessed on October 30,2018).

World Health Organization (WHO). (2019). Cla ssification of diabetes mellitus 2019, Geneva: World Health Organization, pp. 1-37.

Yunita, E.P., Fitriana, D.I., Guna wan, A. (2018). Hubungan antara obesitas, konsumsi tinggi purin, dan pengobatan terhadap kadar a sam urat dengan penggunaan allopurinol pada pasien hiperurisemia. Jurnal Farmasi Klinik Indonesia, $7(1)$, 1-9. https://doi.org/10.1541 6/ijcp.2018.7.1.1

Yunita, E.P. \& Adianingsih, O.R. (2017). Relationships levels of public education in addressing complaints a gainst the behaviour of the disease (The study wa s conducted in Perumahan Bulan Terang Utama Malang City). 17th Asian Conference on Clinical Pharmacy, Theme "Unity

163 www.jurnal.ugm.ac.id/jpkm in Diversity and the Standardisation of Clinical Pharmacy Services", Poster Presentation (ABS280), Surabaya: Faculty of Phamacy, Universitas Airlangga, p. 144.

Zodda, D., Giammona, R., Schifilliti, S. (2018). Treatment strategy for dyslipidemia in cardiovascular disease prevention: focus on old and new drugs. Pharmacy, 6, 1-16. https://doi.org/10.3390/pharmacy6010010 